\title{
Victoria Filminde Mekân-Zamansal Sürekliliğin Dalım Üzerindeki Etkisi
}

\author{
The Effect of Spatio-Temporal Continuity on the Immersion in the Film Victoria
}

Ali Altan Yücel, Görsel İletişim Tasarımı Bölümü, Beykent Üniversitesi

\begin{abstract}
Özet
Derin bir șekilde odaklanma, dâhil olma, dalıp gitme anlamlarına gelen dalım (immersion) terimi, özdeșleșme temelli tüm anlatıların ortak hedefidir. Kişi kendisini okuduğu bir kitaba ya da seyrettiği bir filme kaptırdığında bir dalım yașar. Belirli bir mekân ve zamanda gerçekleșen olayların kesintisiz olarak aktarılması anlatımda mekânzamansal sürekliliği oluşturur. Mekân-zamansal süreklilik özellikle içerdiği gerçekçilik dolayısıyla dalımı oluşturan etmenlerden birisidir. Filmde mekân-zamansal sürekliliği sağlamanın en etkin yolu kurgunun kullanılmamasıdır. Araștırmaya konu olan Schipper'in Victoria adlı filmi tek çekim olması ve gerçekçiliğiyle ile öne çıkmaktadır. Örnek olay incelemesi yönteminin kullanıldığı bu nitel araștırmada, Victoria'daki mekân-zamansal sürekliliğin dalım üzerindeki etkisi araștırılmıștır. Araştırmanın bulgularına göre, gerçekçilik öznel bir kavram olması nedeniyle Victoria'da dalıma göreceli olarak katkı sağlamaktadır. Filmde fiziksel dalım gösterim salonu, geniş çerçeve oranı ve çevresel ses bileșimi aracilığıyla gerçekleşirken, zihinsel dalımda (buradalık) senaryodan kurguya kadar filmin tüm ögelerinin etkisi vardır. Victoria'daki mekânzamansal sürekliliğin dalımı çoğunlukla desteklediği görülmüştür. Ancak zihinsel dalımın öznel bir his olması nedeniyle filmde mekânzamansal sürekliliğin etkisi nesnel olarak saptanamamıștır. Bununla birlikte Victoria'nın bir anlatı filmi olmasından hareketle senaryodaki mekân-zamansal sürekliliğin filmdeki zihinsel dalımın temel etmenlerinden biri olduğu söylenebilir. Zihinsel dalımdaki birincil etmenlerin ise senaryodaki geciktirim ve özdeşleşme unsurları olduğunu söylemek mümkündür. Cünkü seyircinin öyküye olan ilgisini ve katılımını sağlayan temel unsurlar bunlardır. Sonuç olarak Victoria filminde mekân-zamansal sürekliliğin dalımın birincil etmeni olmadı ̆̆ı varsayımında bulunulabilir.
\end{abstract}

Anahtar Sözcükler: Dalım, buradalık, gerçekçilik, tek çekim film, mekân-zamansal süreklilik.

Akademik disipin(ler)/alan(lar): Sinema, film dili.

\begin{abstract}
The term immersion, which means focusing deeply, involvement, and to be engrossed in, is the common objective of all identification-based narratives. A person who becomes wholly absorbed in a book or film, experiences an immersion. The uninterrupted conveyance of events taking place at a certain place and time creates spatio-temporal continuity in the narration. Spatio-temporal continuity is one of the factors that creates immersion, especially because of the realism it contains. The most efficient way to ensure spatio-temporal continuity in the film is to not to use editing. The subject of the research, Schipper's Victoria stands out as a one shot and realist film. In this qualitative research using the case study method, the effect of spatiotemporal continuity on the immersion in Victoria was explored. According to the findings, realism contributes relatively to the immersion in Victoria, as it is a subjective concept. While the physical immersion in the film is created by the screening room, wide aspect ratio and surround sound mix, the mental immersion (presence) is created by the effect of all the elements of the film from screenplay to editing. Spatio-temporal continuity in Victoria mostly supports immersion. However, the effect of spatio-temporal continuity in the film could not be objectively determined because the mental immersion is a subjective feeling. However, considering that Victoria is a narrative film, it can be said that the spatio-temporal continuity in the screenplay is one of the main factors of the mental immersion. It is possible to say that the primary factors in the mental immersion are suspense and identification elements in the screenplay. Because these are the basic elements that provide the audience's interest and participation in the story. Consequently, it can be assumed that spatiotemporal continuity is not the primary factor of the immersion in Victoria.
\end{abstract}

Key Words: Immersion, presence, realism, one shot film, spatiotemporal continuity.

Academical disciplines/fields: Cinema, film language.

- $\quad$ Sorumlu Yazar: Ali Altan Yücel, Görsel İletișim Tasarımı, Beykent Üniversitesi.

- $\quad$ Adres: Beykent Üniversitesi Ayazağa-Maslak Yerleşkesi, Ayazağa Mah., Hadım Koruyolu Cd. No: 19, 34398 Sarıyer/İstanbul.

- e-posta: altanyucel@yahoo.com

- ORCID: 0000-0001-7537-6908

- Cevrimiçi yayın tarihi: 30.12 .2020

- doi: 10.17484 /yedi.803006 


\section{Giriş}

Tarih öncesi çağlarda atalarımızın birbirlerine anlattıkları olayları, ateşin mağara resimleri üzerinde yarattığı ışık oyunları eşliğinde dinlerken yaşadıkları dalım ${ }^{1}$, günümüzün sanal gerçeklik kullanıcılarının yaşadıklarıyla benzerdi. Dalım, özdeșleșmeye dayalı her anlatının ortak hedefidir. Bir șeyin bir sıvı içerisine daldırılması gerçek anlamından türetilmiş olan 'dalım' (immersion) terimi kendini (bir şeye) derinden dâhil etme (Hornby, 1989, s. 620) anlamına gelen bir eğretilemedir (Murray, 1997, s. 99). Dalım, kişinin kendisini sarmalanmış, dâhil edilmiş olarak algıladığı, sürekli bir uyarım ve deneyim akışı ile etkileşim halinde olduğu bir psikolojik durum olarak açıklanabilir (Witmer ve Singer, 1998, s. 227). Dalımı tecrübe eden kişi için öykünün anlatım aracı gözden kaybolur. Bu durumda artık ne okunan kitabın sayfaları, ne seyredilen filmin perdesi fark edilir. Daha da önemlisi kişi o anda dertlerini, tasalarını da unutur. Bir süreliğine öykü dünyası gerçek dünya haline gelir ve gerçek dünyadaki zaman durmuş gibi olur (Brooks, 2003, s. 6). Don Kişot karakteri için romanlardaki kurmaca gerçekliğin asıl gerçeklikten daha gerçek hale gelmesi sürekli bir dalım durumuna örnektir (Murray, 1997, s. 98). Çocukların kendilerini oynadıkları oyuna kaptırmaları da bir dalımdır.

Belirli bir mekân ve zamanda gerçekleșen olayların kesintisiz olarak aktarılması anlatımda mekânzamansal sürekliliği (MZS) oluşturur. MZS, okuyucunun/ seyircinin anlatılanlar ile arasındaki hayali (mekânsal ve zamansal) mesafeyi en aza indirger (Ryan, 2001, s. 130). Anlatımın gerçek yaşam gibi kesintisiz oluşu bir gerçekçilik hissi doğurarak okuyucunun/ seyircinin burada ve şimdide hissetmesini sağlar. Dolayısıyla gerçekçilik dalım ile yakından ilişkili bir kavramdır (Slater, Linakis, Usoh, ve Kooper, 1999; Astheimer, Dai, Göbel, Kruse, Müller ve Zachmann, 1994, s. 190) ve MZS dalımı oluşturan etmenlerden biridir.

Filmde MZS'yi elde etmenin en etkin yolu kurgunun kullanılmamasıdır. Araştırmaya konu olan Victoria (Schipper, 2015) ise tek çekimden oluşan ve gerçekçiliği ile öne çıkan bir filmdir. Bu anlamda filmin yönetmeni Schipper'in sözleri dikkate değerdir: "Bu bir banka soygunu hakkında bir film değil. Bu bir banka soygunu." (Ehrlich, 2015). Film Berlin'e yeni taşınmış bir İspanyol genç kızın yeni tanıştığı arkadaşlarıyla dışarıda geçirdiği gecenin sonunda kendisini bir banka soygununda onlara yardım edeceği, ölümcül olayların içerisinde bulmasını konu almaktadır. Araştırmanın amacı Victoria'da tek çekim ile elde edilen MZS'nin dalım üzerindeki etkisinin saptanmasıdır. Örnek olay incelemesi yönteminin kullanıldı̆̆ bu nitel araştırmada, Victoria filminde MZS dalımın birincil etmeni değildir varsayımında bulunulmuştur.

\section{Kuramsal Çerçeve}

Farklı araçlar farklı dalım türlerini içerir. Bu durum farklı dalım sınıflandırmalarını doğurmuştur. Ryan (2001) yazınsal alandaki dalımı mekânsal, mekân-zamansal, zamansal ve duygusal olmak üzere dört başlıkta incelemiștir (s. 121). Sherman ve Craig (2003) sanal gerçeklik alanındaki dalımı fiziksel ve zihinsel olarak sınıflandırmışlardır (s. 9). Bununla birlikte dalım aynı alanda dahi farklı anlamlarda kullanımları olan bir terimdir. Karışıklığı engellemek adına dalım teriminin bu araştırmada Sherman ve Craig'in (2003) açıkladıkları anlamda kullanıldığını belirtmekte fayda vardır. Buna göre dalım, kişinin fiziksel veya zihinsel olarak bulunduğundan farklı bir ortamda olması hissidir. Fiziksel dalım, bedensel bir ortama girme; teknolojinin kullanımıyla bedenin duyularının tümüyle veya kısmen, sentetik olarak uyarılmasıdır. Zihinsel dalım ise derin bir şekilde dâhil olma, güvensizliğin askıya alınması, katılım olarak tanımlanır. Zihinsel dalım sanal gerçeklik alanında benimsenmiş olan 'buradalık' (presence) terimiyle eşanlamdadır (s. 9). Buradalık fiziksel dalıma gösterilen insani bir tepkidir (Slater, 2003, s. 2). Bu nedenle nesnel bir tanıma ve ölçüme pek uygun olmayan, öznel bir histir (Sheridan, 1992, s. 121). Örneğin bir rengin dalga boyu dağılımının nesnel olarak tanımlanması mümkünken, o rengin algısı insandan insana farklılık gösterebilir. Buna göre fiziksel dalım dalga boyu dağılımına, zihinsel dalım (buradalık) ise renk algısına benzetilebilir (Slater, 2003, s. 1-2). Araştırmada Sherman ve Craig ile Ryan'ın dalım sınıflandırmaları esas alınmıștır. Çünkü bunlar film aracına daha uygun düșen sınıflandırmalardır. Araștırma Victoria'daki tek çekimin yarattığı MZS'nin dalım üzerindeki etkisine odaklanmaktadır. Victoria özdeşleşmeye dayalı bir anlatıya sahip, dramatik bir filmdir. Özdeşleşme dalımla koşut olarak ilerleyen ve aynı amacı güden bir olgudur. Dolayısıyla Victoria'nın anlatısı seyircinin dalımını amaçlar şekilde kurulmuştur.

\footnotetext{
${ }^{1}$ Dalım, İngilizcedeki immersion sözcüğüne karșılık olarak, yazar tarafından türetilmiș bir sözcüktür. Immersion terim anlamıyla bir dalma deneyimine karşılık gelir. Türkçe kaynaklarda terim için kullanılan daldırma sözcügünün bu anlamı karşılayamadığı düşüncesiyle yeni bir sözcüğün türetilmesine gerek duyulmuştur.
} 


\subsection{Gerçekçiliğin Dalım Üzerindeki Etkisi}

Aristoteles (2018) ozanın işini, olmuş şeyleri değil, olabilecek şeyleri, yani olanaklı şeyleri olasılık ya da zorunluluk esasına göre anlatmak olarak tanımlar. Çünkü olanaklı olan inandırıcı olandır (s. 23). 0 halde gerçekçilik anlatılan olayların gerçek yaşamda gerçekleşebilir olmasına bağlıdır. Astheimer vd. (1994) ise sanal gerçeklik alanındaki araştırmalarında gerçekçiliğin temelde gerçekliğin belirli bir temsile çevrilmesindeki sadakat ile ilgili olduğunu açıklarlar (s. 204).

Gerçekçilik dalımı fazlasıyla etkileyebilmektedir. Astheimer vd.'ye (1994) göre yüksek derecede bir dalım gerçekçi bir sanal ortamla eşdeğerdir (s. 190). Kullanıcı için temsil (sanal ortam) inandırıcılığı oranında gerçekçidir (Astheimer vd., 1994, s. 205). Bununla birlikte gerçekliğin yapay ve hileli bir biçimde kurgulanması gerçekçiliği ortadan kaldırabilir. Astheimer vd. (1994) buna Arcimboldo'nun ölü doğa tablolarını örnek gösterirler. Örneğin ressamın Sommer (Yaz) adlı tablosundaki meyveler, son derece gerçekçi bir şekilde resmedilmiş olsalar dahi bunların bir insan portresini oluşturur biçimdeki kurgulanışı izleyicide gerçekçi bir izlenim yaratmaz (bkz. Şekil 1). Bu algının gerçekçilik üzerindeki etkisidir (s. 205).

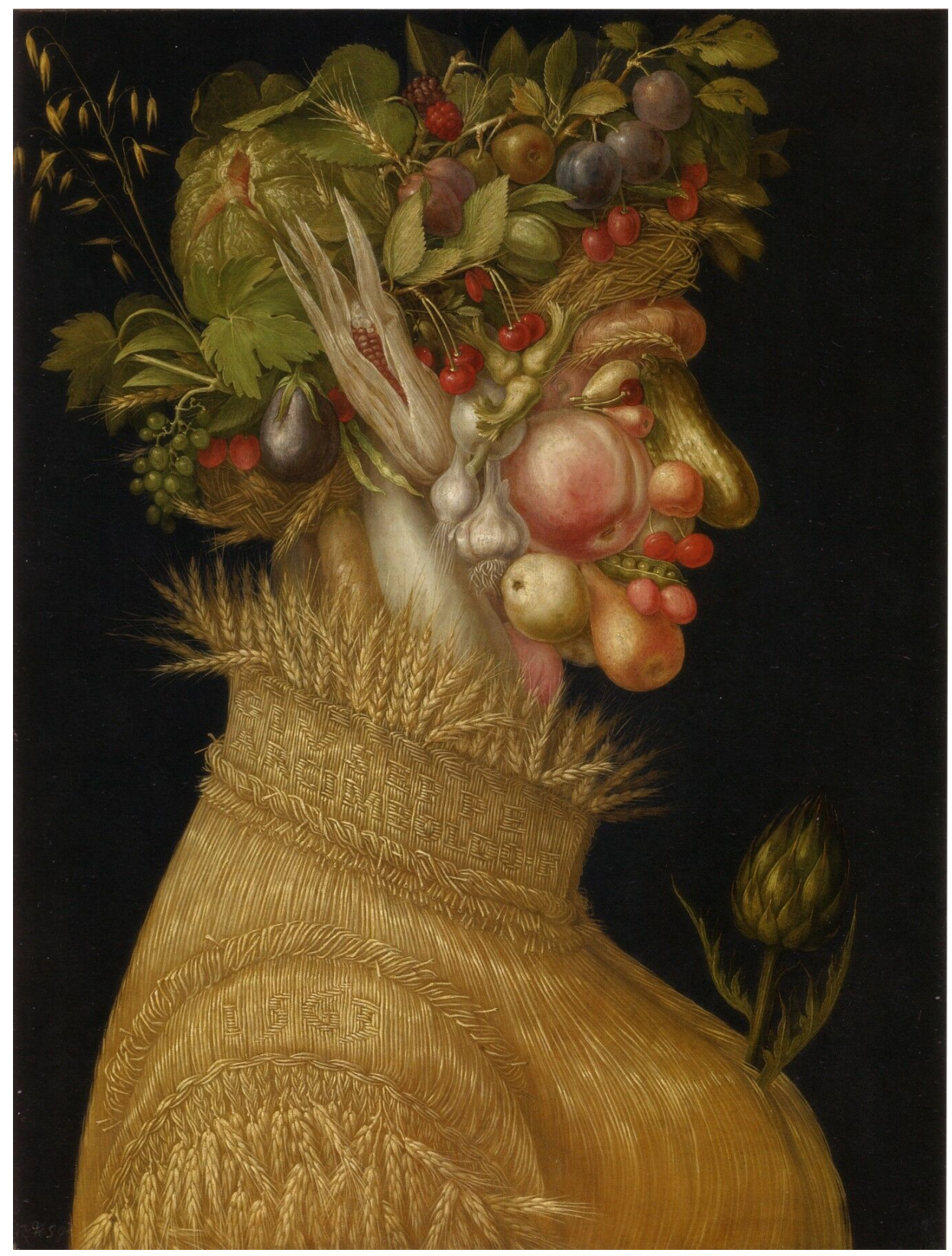

Şekil 1. Sommer, G. Arcimboldo, 1563 (Kunsthistorisches Museum Wien, CKHM-Museumsverband). 
Benzer bir örnek Ayzenștayn'ın Bronyenosyets Potyomkin (Potemkin Zırhlısı, 1925) adlı filminden verilebilir. Filmde uyuyan, bakan ve doğrulmuş pozlardaki üç ayrı aslan heykelinin peşi sıra kurgulanışı (montaj) seyircide uyanarak doğrulan taştan bir aslan heykeli algısını oluşturmaktadır (bkz. Şekil 2). Buradan hareketle filmde kurgunun gerçekçiliği azalttığı sonucuna varılabilir.

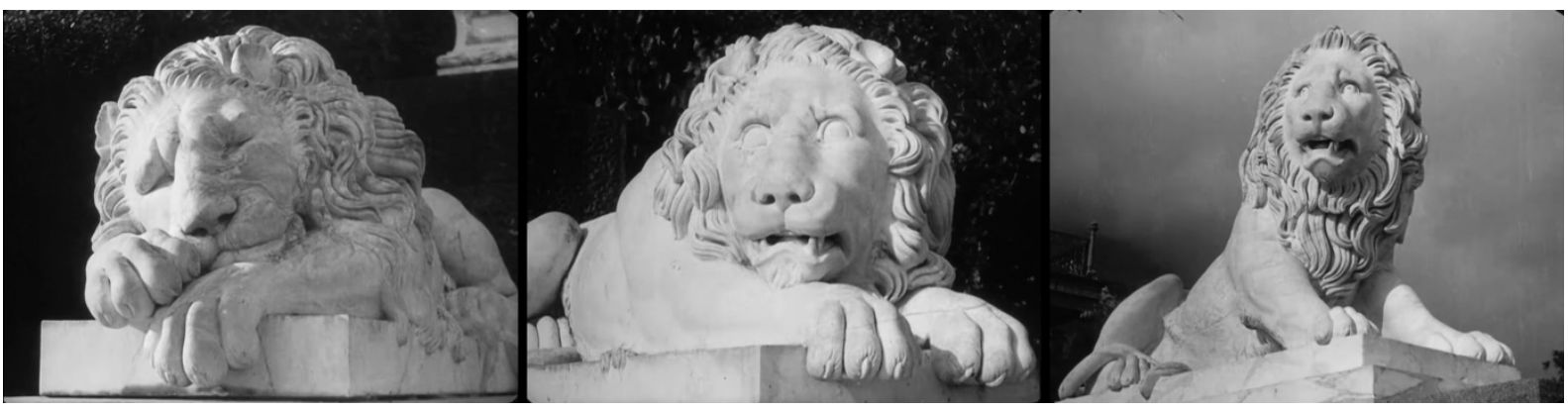

Şekil 2. Bronyenosyets Potyomkin, S. M. Ayzenștayn, 1925 (Sovyetler Birliği: Mosfilm).

Bununla birlikte gerçekçilik öznel bir kavramdır ve kişinin kendisiyle doğrudan ilişkilidir (Astheimer vd., 1994, s. 190). Farklı uzmanlıklara sahip kişilerin aynı temsil ile ilgili gerçekçilik izlenimleri de farklı olacaktır (Astheimer vd., 1994, s. 205-206). Örneğin bir tarihçi ve bir film yönetmeninin tarihsel bir film ile ilgili edinecekleri gerçekçilik izlenimleri birbirinden çok farklı olabilir. Tarihçi filmin filmsel özelliklerinden çok tarihsel özelliklerinin farkına varırken, film yönetmeni için tersi bir durum söz konusu olabilir. Bu da aynı filmle ilgili iki farklı gerçekçilik izleniminin doğmasına yol açar.

Benzer bir durum kişilerin görsel, işitsel veya dokunsal duyarlılıklarındaki farklılıklarla ilgili olarak da ortaya çıkabilir (Slater ve Usoh, 1993, s. 91). İnsanların belirli bir durum içerisindeyken bir temsil dizgesini diğerlerine tercih etme eğiliminde oldukları iddia edilmektedir. Örneğin kimi insanlar sorunları ağırlıklı olarak imgelerle düşünüp taşınırken kimileri iç seslerine başvurabilmektedir. Buradan hareketle Slater ve Usoh (1993) görsel ağırlıklı bir sanal ortamda temsil dizgesi tercihi görsel olan kişilerin diğer farklı tercihli kişilere göre daha yüksek derecede bir buradalık yaşayacakları hipotezini ortaya koyarlar (s. 92).

Diğer yandan sanal gerçekliği kullanarak uçuş korkusuna yönelik maruz bırakma tedavisi (exposure therapy) uygulayan psikologlar katılımcının görsel olarak gerçekçi olmayan bir sanal ortamda dahi gerçek bir uçakta gösterilen kaygı belirtilerinin çoğunu yaşadığını saptamışlardır (Hodges, Rothbaum, Watson, Kessler ve Opdyke, 1999, s. 11).

Sonuç olarak gerçekçilik tıpkı zihinsel dalım (buradalık) gibi öznel bir kavramdır. Bu nedenle gerçekçiliğin dalım üzerindeki etkisi görecelidir.

\subsection{Filmde Fiziksel Dalım}

Seyircinin görüş alanını bütünüyle kaplayan panoramik resimler ve gök perdeleri (cyclorama) fiziksel dalıma yönelik en eski uygulamalardır. Sinema ise karanlık salonu ve büyük perdesiyle başlı başına fiziksel dalıma dayalı bir buluştur. Sinema seyircisinin filmi konuşmadan seyretme terbiyesi de bu dalıma bir katkı sağlar. Ses, renk, üç boyut ve geniş ekran (Cinemascope) gibi sinemaya sonradan eklenen her özellik sinemayı gerçekliğe daha çok yakınlaştırarak seyircinin fiziksel dalımının arttırılmasını sağlamıştır. Dalımsal sinema (immersive cinema) ise sinemada bu etkinin getirildiği son noktadır. Gökevlerindeki kubbe salonlu Fulldome, yatay $70 \mathrm{~mm}$ formatlı IMAX, üç perdeli Cinerama ve ScreenX film gösterim sistemlerinin devasa perdeleri seyirciyi bütünüyle içine alır. Bu nedenle dalımsal sinemada seyirci perdedeki eylemi uzaktan seyretmez, kendisini doğrudan eylemin içerisinde bulur (Yu, Neafus, ve Wyatt, 2016, s. 34). Bunların yanı sıra benzetimin gerçekçiliğini artırmak amacıyla titreşim, hava, su, sıcaklık gibi ögelerle zenginleştirilmiş, dört boyutlu (4D) olarak adlandırılan sinema gösterimleri de söz konusudur. Son yıllarda giderek yaygınlaşan 'sanal gerçeklik' $(V R)$ ise seyirciyi içine alan 360 derecelik küresel görüntüsüyle fiziksel dalımı öncelikli amaç edinmiş bir araçtır.

Ses ise doğası itibariyle dinleyicisini fiziksel olarak saran bir niteliğe sahiptir. Sinemada ses alanında yaşanan gelişmeler filmin yarattığı fiziksel dalımı arttırmıştır. Bir kanallı mono ve iki kanallı stereo sistemlerin ardından geliştirilen altı kanallı 5.1, sekiz kanallı 7.1 ve şimdilerdeyse yüz yirmi sekiz kanala kadar imkân tanıyan Dolby Atmos teknolojisi filmde fiziksel dalımı destekleyen çevresel ses (surround sound) sistemleridir. 


\subsection{Filmde Zihinsel Dalım}

Özdeşleşme temelli bir filmin her bileşeni zihinsel dalımın gerçekleşmesinde pay sahibidir. Senaryo, içerdiği olay örgüsü, yer, zaman, başkarakter, çatışma, vb. temel yazınsal ögelerle zihinsel dalımı yaratır. Ryan'ın (2001) yazınsal alandaki dalım sınıflandırmasından hareketle, senaryo kendi içerisinde mekânsal, mekânzamansal, zamansal ve duygusal olmak üzere dört ayrı zihinsel dalım türü barındırır. Buna göre mekânsal dalım öykünün yer aldığı veya öyküde konu edilen mekânla ilişkili yaşanılan dalımdır (s. 121). Anlatımda uzun betimlemelere başvurmaksızın uygun adların kullanımı seyircide bir mekân hissinin oluşturulmasının etkin bir yoludur (Ryan, 2001, s. 127). Mekân-zamansal dalım belirli bir mekân ve zamanda meydana gelen olayların eşzamanlı anlatımı sonucunda gerçekleşir. Bu tür dalımda okuyucu/seyirci anlatılan olayın meydana geldiği mekâna ve zamana nakledilmiş olur (Ryan, 2001, s. 130). Zamansal dalım okuyucunun/seyircinin olay örgüsüne olan tepkisidir (Ryan, 2001, s. 121). Gerçekleşecek zamansal dalımın yoğunluğu olay örgüsünde yaratılan 'geciktirim' (suspense) unsuruna bağlıdır (Ryan, 2001, s. 143). Geciktirim, seyircinin zor durumlardaki karakterlerin akıbetleriyle ilgili hissettiği belirsizliğe dayanır (Cawgill, 2007, s. 131). Geciktirimde çözülümün gecikmesi nedeniyle okuyucunun/seyircinin duygusal deneyimi gerginleşir (Bell, 2011). Ryan (2001) bu geciktirim unsurunu, yoğunluğuna göre azalan şekilde dört türe ayırır:

1. Ne Geciktirimi (What Suspense): Sonra ne olacak (s. 143)?

2. Nasıl Geciktirimi (How Suspense): Nasıl olmuş (s. 144)?

3. Kim Geciktirimi (Who Suspense): Kim yaptı? Polisiye (whodunit), cinai romanlarda yer alan geciktirim türüdür (s. 144).

4. Geciktirimötesi (Metasuspense): Nasll sona erecek (s. 145)?

Geciktirimin yaratılmasında çeșitli senaryo yazım araçlarından faydalanılır. Basit bir ifadeyle sahnede seyircinin bildiği bir gerçeği karakterin bilmemesi șeklinde tanımlanabilecek olan 'dramatik ironi' (dramatic irony) bu araçlardan birisidir. Örneğin filmde bir karakterin evden anahtarını unutarak çıkışının seyirciye gösterilmesi sahnede dramatik ironi yaratır. Filmde seyircinin bir gerçeği karakterle aynı zamanda öğrenmesi sürpriz, karakterin bildiği bir gerçeği bilmemesi ise esrar olarak adlandırılır (Başol, 2010, s. 393). Diğer bir araç 'hazırlık ve sonuçtur' (preparation and aftermath). Hazırlık, seyircinin ve karakterin kendilerini yaklaşan bir dramatik sahneye hazırladıkları sahnedir. Sonuç ise karakterin ve seyircinin bu dramatik sahneyi sindirdikleri sahnedir (Howard ve Mabley, 1995, s. 70). Örneğin bir sporcunun bir yarışa hazırlanışının anlatıldığı bir filmdeki tüm antrenman sahneleri hazırlık, sporcunun yarışta galip gelmesi üzerine yaşadığı sevincin gösterildiği sahne ise sonuç işlevindedir. 'Ekme ve ödeme' (planting and payoff) senaryodaki hazırlık ile ilgili bir başka geciktirim aracıdır. Bu yöntemde senaryoda yer verilen ögeler ileriki sahnelerde tekrarlanır ve sonunda anlamlı veya olağan bir şekilde kullanılır (Howard ve Mabley, 1995, s. 72-73). Çehov'un oyundaki ögelerin gerekliliğine yönelik olarak söylediği "Eğer 1. aktta duvarda asılı bir tabancanız varsa bu silah 3. aktta ateşlenmelidir" (aktaran Rayfield, 1997, s. 203) sözü bu konuya örnektir. Burada duvarda asılı olan tabancanın seyirciye önceden gösterilmesi ekme, ateşlenmesi ise ödemedir. Geciktirim silahın seyirciye gösterilmesinin ardından bașlamıș olur. Geciktirime yönelik diğer bir araç da 'gelecek ögeleri ve bildirme' (elements of the future and advertising) olarak adlandırılır. Aslında bir anlamda ekme ve ödeme bu doğrultuda çalışan araçlardır (Howard ve Mabley, 1995, s. 74). Karakterlerin önsezileri, kehanetleri, şüpheleri, hayalleri, arzuları, planları, verdikleri sözler tümüyle geleceğe ait ögelerdir (Howard ve Mabley, 1995, s. 75). Karakterlerin gelecekte yaşayabilecekleri bu deneyimlerin seyirciye duyurulması veya gösterilmesi ise bildirmedir (Howard ve Mabley, 1995, s. 74).

Bu noktada Ryan'ın ve Aristoteles'in anlatıdaki dalıma yönelik görüşlerinin kıyaslanması aydınlatıcı olacaktır. Ryan'ın zamansal dalımın yoğunluğunu olay örgüsündeki geciktirime bağlamasına karşın, Aristoteles (2018) tragedyanın ruhu alıp götürmesini sağlayan en önemli ögelerin öyküdeki 'baht dönüşleri' (peripeteiai) ve 'tanımalar' (anagnôriseis) olduğunu yazmıştır (s. 17). Örneğin Sophokles'in (M.ö. 428/2012) Kral Oidipus adlı tragedyasında Oidipus'un öz babasını öldürmüş ve öz annesiyle evlenmiş olduğunu öğrenişi baht dönüşüne yol açan bir tanıma örneğidir. Olay örgüsünün önemli birer parçası olan baht dönüşü ve tanıma, trajedinin zirvesinde ortaya çıkarak seyircinin arınmasını sağlayan araçlardır (Anagnorisis, 2017). Seyirci bu yolla anlatının sonunda bir gerçeği başkarakter ile aynı anda öğrenerek bir sürpriz yaşar. Geciktirimde ise seyirci anlatı boyunca bildiği bir gerçeğin sonucunu merak eder.

Duygusal dalım ise seyircinin karakterlerle özdeşleşmesi sonucunda yaşadığı dalımdır (Ryan, 2001, s. 121). Özdeşleşmenin gerçekleşebilmesi için öncelikle karakterlerin seyirciye tanıtılmaları gerekir. Buna sergileme (exposition) adı verilir. Ancak sergileme filmin yalnızca başlangıcında yer almaz, film boyunca devam eder (Egri, 1960, s. 235). Seyirci filmin sonuna kadar karakterler hakkında yeni bilgiler edinmeyi 
sürdürür. Bu yolla karakterlerin bilinmeyen geçmişleriyle ilgili geciktirimlerin de yaratılması sağlanmış olur.

Dekor, kostüm, aksesuar, oyunculuk, görüntü, ses ve kurgu unsurlarının gerçekçiliği filmde zihinsel dalıma katkı sağlar. Filmin dekor, kostüm ve aksesuar ögelerinin sahici görünümü seyircinin filme katılımını arttırır. Oyunculuktaki doğallık da benzer bir etki oluşturur. Elbette bu etki tiyatrodaki kadar güçlü değildir. Çünkü tiyatrodaki gerçek ve canlı oyunculara karşılık sinemada oyuncuların yalnızca kaydedilmiş görüntüleri vardır. Bu da tiyatro oyuncusunun sinemada mümkün olamayacak bir ölçüde seyirciyle bağlantı kurmasına olanak tanır (Howard ve Mabley, 1995, s. 7). Filmin görüntüsünü oluşturan ögelerin tümü (çizgi, biçim, cisim, değer, renk, doku, yön, hareket, vd.) neredeyse her seyircide benzer duygusal tepkiler yaratan, evrensel bir dile sahiptir (Mascelli, 1965, s. 200). Gözün görüş açısına eşdeğer objektif kullanımı, doğal tonlar ve renkler görüntünün gerçekçiliğini destekler. Görüntüdeki derin odak, üst üste düşen düzlemler ve perspektif seyircinin derinlemesine alan algısını arttırarak bir gerçeklik yanılsaması oluşturur. Filmde sesin, kaynağı çerçeve içi veya dışı fark etmeksizin seyircinin gördüklerinin gerçekliğine ikna olmasını sağlayıcı bir ișlevi vardır. Ancak filmin atmosferini asıl oluşturan, kaynağı görünmeyen, çerçeve dıșı sestir (Sobchack ve Sobchack, 1987, s. 182-185). Müzik ise sahnedeki bir durumun vurgulanmasında ve seyircinin duygularının harekete geçirilmesinde etkin bir araçtır (Sobchack ve Sobchack, 1987, s. 188). Ancak fon müziği kullanımı sahne içi müziğin aksine gerçekçi olmayan bir yöntemdir (Sobchack ve Sobchack, 1987, s. 189). Filmde müzik tekrarı da önemli bir anlatım aracıdır. Bu yolla öyküde yinelenen, benzerlik veya karşıtlık içeren durumlar vurgulanabilir (Sobchack ve Sobchack, 1987, s. 188). Kurgulanmamış, ham görüntü seyircide seyrettiğinin gerçek olduğu hissini uyandırır. Bu nedenle filmde kurgunun kullanılmamasının gerçekçiliği ve dolayısıyla dalımı arttıııcı bir etkisi vardır.

\subsection{Filmde Mekân-Zamansal Süreklilik}

Filmde MZS'yi içe kesme (insert/ cut-in), dışa kesme (cutaway), bölünmüş ekran (split screen), bindirme (superimposition)... vb. kurgu araçları ile elde etmek mümkünse de aslında bunun en etkili yolu kurgunun hiç kullanılmamasıdır. Anlatımda pek çok kısa çekim yerine tek bir uzun çekime başvurulmasının MZS'nin sağlanmasının ötesinde işlevleri vardır. Uzun çekim filmin gösterim süresi ile anlatı süresini (diegetic time) eşitler. Özellikle genel çekim ve hareketli kamera ile birlikte kullanıldığında uzun çekim çok güçlü bir gerçek mekân ve zaman hissi yaratır. Buna karşın sık kesmeler gerçek mekânı parçalar (Sobchack ve Sobchack, 1987, s. 158-159). Aslında kesme bir anlamda içerikten ziyade biçime dikkati çeken, yapay bir aygıttır. Filmde ne kadar az kesme olursa sergilenen eylem de o kadar doğal, kendiliğinden ve nesnel görünür (Reisz ve Millar, 1953/2014, s. 283). Bazin, filmde gerçekliğin kurgu araçlarının kullanımıyla değiştirilmesindeki tehlikeye işaret etmiştir (Reisz ve Millar, 1953/2014, s. 284). Ona göre sahnedeki bir olayın özü, iki veya daha fazla etmenin eşzamanlı varlığına bağlı olduğunda, montaj yasaktır. Bu tür ögeler aynı çerçeve içerisinde gösterilmelidir (Bazin, 1967/2005, s. 50). Tek bir çekim içerisinde gerçekleşen her eylem, kurgucunun duruma müdahale etmediğinin bir kanıtıdır. Seyirciye gerçek bir olaya tanık olduğu ve işin içinde hiç hile olmadı̆̆ı duygusunu yaşatır (Sobchack ve Sobchack, 1987, s. 158). Özetle uzun çekim filmin gerçekçiliğini arttırır.

Öte yandan anlatı özünde kurgudur. Anlatımda yalnızca gerekli olan ögelere yer verilir ve olayların oluş sırasına sadık kalınması zorunluluğu yoktur. Aristoteles (2018) öyküyü birlik ve bütünlük arz eden bir eylemin taklidi olarak tanımlar. Ona göre varlığı ve yokluğu hissedilmeyen şey bütünün bir parçası değildir (s. 22). Elbette görüntü kurgusunun filmden dışlanması filmi kurgudan bütünüyle yoksun bırakmaz. Bu durumda kurgu, tiyatroda olduğu gibi senaryoda ve sahnelemede (mizansen) varlığını sürdürür. Sanatsal performansını tek çekim içerisinde süreklilik ile sergileyen sinema oyuncusu, Benjamin'in (1935/2013) ifade ettiği filmsel araçların müdahalesinden (s. 65) büyük ölçüde bağımsızdır. Bu süreklilik oyuncunun filme alınmasıyla yitirmiș olduğu halesini (Benjamin, 1935/2013, s. 68) bir ölçüde geri almasını sağlar ve zihinsel dalıma olan katkısını arttırır. Uzun çekim filmde sabit kamera ve genel çekim ölçeğiyle bir arada kullanıldığında seyirciyi de bir tiyatro oyunundaki kadar özgür kılar. Çünkü bu tür bir çekimde seyircinin yönetmenin göstermek istediği yere bakma zorunluluğu yoktur. Anlatımın tek bir çekim içerisinde gerçekleştirilmesi çerçeve içi düzenlemenin önemini arttırır. Bu nedenle bu tür çekimlerde her ögenin rahatlıkla görülebilmesi için genellikle derin odaklı (deep focus) görüntü tercih edilir (Sobchack ve Sobchack, 1987, s. 156).

Eğer tersine bir amaç söz konusu değilse sahnedeki oyunun dramatik yoğunluğunun seyircinin ilgisini kaybetmeyecek bir şekilde düzenlenmesi gerekir. Senaryodaki geciktirim ve çatışma, görüntüdeki hareket, sesteki diyalog, efekt ve müzik ögeleri sahnenin dramatik yoğunluğunu arttırma yetisine sahip araçlardır. 


\section{Araştırma Soruları}

Araştırmanın soruları aşağıdaki gibidir:

AS1: Victoria filminde gerçekçilik dalımı nasıl etkilemektedir?

AS2: Victoria filminde fiziksel dalım nasıl gerçekleşmektedir?

AS3: Victoria filminde zihinsel dalım nasıl gerçekleşmektedir?

AS4: Victoria filminde mekân-zamansal süreklilik dalımı nasıl etkilemektedir?

\section{Yöntem}

Nitel yaklaşımın benimsendiği bu araştırmada keşfedici örnek olay incelemesi yönteminden yararlanılmıștır. Örnek olay incelemesi, sınırlı bir sistemin derinlemesine betimlendiği ve incelendiği bir yöntemdir (Merriam, 2015, s. 40). Bu yöntem en çok nasıl ve neden sorularının sorulduğu araștırmalar için uygundur (Yin, 2014). Örnek olay incelemesi daha sonraki araştırmalar için ipuçları ve fikirler bulunmasına da imkân tanır (Simon, 1978, s. 206). Keşfedici türdeki örnek olay incelemesi ise varsayıma yönelik bir formülleştirme için gereken verinin henüz elde edilmediği, görece yeni bir alanı keşfeden bir araştırmanın ön adımı olarak uygulanır (Mills, Eurepos ve Wiebe, 2010, s. 372). Filmsel dalım ile ilgili araştırmalar hala keşfedici bir evrededir. Dolayısıyla bu araştırma ileriki araştırmalara dair araştırma sorularının ve yöntemlerinin tanımlanmasına katkı sağlayabilir (Yin, 2014, Glossary).

Araştırmanın tasarımında tekli örnek olay incelemesi ve bütünsel çözümleme kullanılmıştır. Tek bir olayın bulgularının genelleştirilmesi nicel ve nitel araştırmaların ortak sorunudur. Örnek olay araştırmacılarının farkı, var olan bir kuramla hareket etmektense yeni bir kuram veya açıklama geliştirmeye çalışmalarıdır (Mills, Eurepos ve Wiebe, 2010, s. 371). Yin (2014) de örnek olay incelemelerinin tıpkı deneyler gibi kuramsal savlara genelleştirilebileceğini ancak bunun kitle veya evrenler için geçerli olmadığını belirtir.

Victoria öncelikle tek çekimden oluşması, gerçekçi tarzı ve sürükleyici dramatik yapısından ötürü araştırmaya örnek olay olarak seçilmiştir. Film ilk olarak sinemada seyredildikten sonra araştırma kapsamında bir monitörde pek çok defa seyredilmiştir. Yapılan gözlemler not alınarak film derinlemesine çözümlenmiştir.

\section{Bulgular}

\subsection{AS1: Victoria'da Gerçekçilik}

Victoria, fon müziği içeren sahneleri dışında tümüyle gerçekçi tarzda bir filmdir. Araştırmada gerçekçilik ile ilgili bulgulara filmin diğer ögeleriyle olan bağlantıları nedeniyle diğer bölümlerde yer verilmiştir.

\subsection{AS2: Victoria'da Fiziksel Dalım}

Victoria, geleneksel sinema gösterimine yönelik, monoskopik olarak çekilmiş bir filmdir. Karartılmış ve yalıtılmış bir mekân olarak filmin gösterildiği sinema salonu seyircinin fiziksel dalımını gerçekleştiren birincil unsurdur. Dahası salonun karanlığı Victoria'nın gece sahneleriyle örtüşerek, bir nevi filmin devamı şeklinde fiziksel dalıma katkı sağlamaktadır. Filmin geniş çerçeve oranı ve çevresel ses bileşimi fiziksel dalımı sağlayan diğer etmenlerdir.

\subsection{AS3: Victoria'da Zihinsel Dalım}

\subsubsection{Senaryo}

\subsubsection{Mekânsal dalım}

Victoria'da Berlin ve Madrid şehir adları karakterler tarafından diyaloglarda tekrarlı olarak kullanılmaktadır. Filmin açılışındaki gece kulübü mekânının, sonrasında karakterler tarafından simetrik bir biçimde tekrar ziyaret edilişi, seyircinin mekânsal koordinasyonunu sağlamasına imkân tanımaktadır. Aynı işlev filmde çatı ve kafe mekânlarının diyaloglardaki tekrarları aracılı̆̆ılyla sözel olarak yerine getirilir. Filmin başlarında Sonne Victoria'yı çatıya davet eder. Çatıda Victoria Sonne'ye çalıştığı kafeye dönmesi gerektiğini söyler. Hatta kafenin yerini (seyircinin göremeyeceği şekilde) çatıdan ona işaret eder. Sonrasında birlikte kafeye giderler. Filmin sonlarında polisten kaçarlarken Victoria "Çatıya mı gidiyoruz?" diye sorar. 


\subsubsection{Mekân-zamansal dalım}

Mekân-zamansal dalım Victoria'nın bütünü için geçerlidir. Filmin gerçek zamanlı yapısı seyircinin sürekli olarak burada ve şimdide hissetmesini sağlamaktadır.

\subsubsection{Zamansal dalım}

\subsection{Ne geciktirimi}

Victoria'da ne geciktirimi filmin bütününde vardır. Seyirci daha en bașta kendi kendine "bu yabancı şehirdeki bu yalnız kızın bașına ne gelecek?” sorusunu sorar ve filmin sonuna kadar öykünün her aşamasında bu sorulara yenilerini ekler.

Victoria'da dramatik ironi filmin bütününe yayılmıștır. Örneğin banka çalışanları soyulacaklarından, polisler binadan ayrılan bebekli çiftin aradıkları kişiler olduğundan habersizlerdir. Ne taksici ne otel çalışanları bu çiftin polisten kaçtığını bilmektelerdir. Boxer'in mafyaya borcunu ödemesi için ne tür bir iş yapması gerektiğini başlangıçta arkadaşları, Victoria ve seyirci dâhil kimsenin bilmemesi ise bir esrar örneğidir. Sonrasında bu işin bir banka soygunu olduğunun öğrenilmesi karakterler ve seyirci için bir sürprizdir.

Filmde Victoria'nın arkadaş arayışı hazırlık, yeni tanıştığı dört arkadaşla birlikte bira içmesi, sonrasında onlara yardımcı olması sonuçtur. Sonne'nin film boyunca Victoria'ya olan ilgisi hazırlık, öpüşmeleri sonuçtur. Karakterlerin marketten bira çalmaları, otomobilleri kaçırmaları sonraki banka soygununun hazırlığı işlevindedir. Kapalı otoparktaki soygun provası hazırlık, soygun ise sonuçtur.

Kafe sahnesi ekme işlevi gören diyaloglar içermektedir. Burada Sonne Victoria'nın kafedeki saatlik kazancını çok düşük bulduğunu söyler. Victoria da alaylı bir şekilde "patronumu öldürmeliyim" der ve Sonne "bence de" diyerek yine alaylı şekilde onu onaylar. Sonrasında Victoria Sonne'ye piyanoda Liszt'in Mefisto Valsi'ni çalar. Bunun üzerine Sonne'nin eserin şeytan temasına yönelik olarak söylediği "şeytanı severim" sözünü Victoria "ben de" diyerek onaylar. Devamında gelişen olaylar onları banka soymaya, polisle çatışmaya ve bebek kaçırmaya kadar götürecektir. Tüm bu suç içerikli sahneler kafedeki diyalogların birer ödemesidir.

Victoria'daki gelecek ögeleri ve bildirmenin ilk örneği filmin başlangıcındadır. Giriș ücretini ödemedikleri için gece kulübüne alınmamaları üzerine Blinker'in girişteki görevliye söylediği "Bir gün bu mekân bizim olacak anladın mı? Mekânını satın alacağız!" sözleri bildirme işlevindedir. Bu sözler ciddi olmasa da karakterin arzusunu içermektedir. Karakterlerin soygun sonrasında bu mekâna geri dönerek etrafa para saçmaları bu arzunun bir ödemesidir. Bir başka bildirme örneği Sonne’nin Victoria'yı çatıda bira içmeye davet etmesidir. Sonne'nin Victoria'dan Boxer için yardım isterken söylediği “Oraya gidip sonra da seni geri getireceğiz. Sorun çıkmayacak." sözleri ve mafya patronunun banka soygununu tarif edişi de bildirmedir. Victoria'nın Sonne'yle birlikte sığındıkları dairedeki anneye söylediği "Bebeğin beş dakika içinde şu dükkânda olacak." ve otele girdiklerinde Sonne'ye söylediği "Odayı tutabilmek için onlara bir hikâye uyduracağım." sözleri de filmdeki diğer bildirme örnekleridir.

\subsection{Nasil geciktirimi}

Victoria'da nasıl geciktirimi karakterlerin geçmişleriyle ilgili diyaloglar aracılığıyla sağlanmaktadır. Boxer Victoria'ya daha önce hapse girdiğinden bahseder. Victoria Sonne'ye konservatuar geçmişinden söz eder. Sonne Victoria'ya Boxer'in hapishanedeyken mafyaya borçlanmış olduğunu anlatır. Tüm bu bilgilendirmeler seyircinin bu olayların nasıl gerçekleştiğini merak etmesine yol açmaktadır.

\subsection{Kim geciktirimi}

Victoria'da kim geciktirimi filmdeki mafya teması ile ilgili olarak yaratılmaktadır. Kafede Boxer ve Sonne arasında geçen diyalogdaki "aradı", "onu arayıp olmayacağını söyle” sözleri Victoria'nın ve seyircinin zihnindeki ilk kim sorusunu uyandırır. Birlikte mafyaya gidişlerinde de aynı geciktirim sürer. Aralarında Boxer dıșında görüșecekleri kişinin kim olduğunu bilen yoktur.

\subsection{Geciktirimötesi}

Victoria'daki geciktirimötesi doğal olarak filmin sonuna doğru ortaya çıkmaktadır. Filmde sona yaklaşıldıkça seyirci Victoria'nın ve Sonne'nin içine düştükleri durumdan kendilerini nasıl kurtaracaklarını giderek artan bir șekilde merak eder.

\subsubsection{Duygusal dalım}

Victoria filmi bir gece kulübündeki kalabalık içerisinde yalnız bașına dans eden bir genç kız (Victoria) ile açılmaktadır. Sonrasında Victoria'nın kulüpteki barmenle sohbet etmeye çalışması başkaraktere yönelik ilk önemli bilgilendirmedir: bu kız arkadaşlık arayışındadır. Barmenin ilgisiz tavrı karşısında Victoria'nın 
yaşadığı hayal kırıklığı seyircinin onunla hızlıca özdeşleşmesini sağlar. Devamında Victoria filmin diğer karakterleri Sonne, Boxer, Blinker ve Fuss ile tanışır. Seyirci burada yalnızca Victoria için endişelenir. Sonrasında bu dört yakın arkadaşı tanıdıkça seyirci onlarla da özdeşleşir ve onlar için de endişe duyar.

\subsubsection{Dekor, kostüm ve aksesuar}

Victoria'da dekor kullanılmamıștır. Filmin çekimleri tümüyle gerçek mekânlarda, gerçekçi kostümler ve aksesuarlar ile gerçekleştirilmiştir.

\subsubsection{Oyunculuk}

Victoria'daki oyunculuk gerçekçidir. Oyunculukta istenilen doğallı̆̆ın elde edilebilmesi için doğaçlamadan faydalanılmıştır. Ayrıca bakış açısını ve tempoyu yönlendirmesi nedeniyle oyunculuğun filmin dilinde belirleyici bir rolü vardır.

\subsubsection{Görüntü}

Victoria'nın görüntüsündeki sığ alan derinliğine karşın üst üste düşen düzlemler ve perspektif seyircinin derinlemesine alan algısını arttırmaktadır. Filmin aydınlatma yaklaşımı doğalcıdır. Filmin ilk yarısını oluşturan gece sahneleri mekânların kendi yapay aydınlatma kaynakları kullanılarak, düşük anahtar tarzında aydınlatılmıştır. Filmin ikinci yarısından itibaren beliren alaca karanlığın sağladığı doğal gök ışığı dış mekânlardaki ana aydınlatma kaynağı işlevindedir. Sahnelemede oyuncular aydınlatma kaynaklarına göre konumlandırılarak sahnelerdeki anlam desteklenmiştir. Sonne'nin Victoria'dan kendilerine yardımcı olmasını istediği kafe sahnesi buna örnektir. Bu sahnede Sonne konuyu Victoria'ya açılarken birlikte büfenin yanına otururlar ve yüzleri büfenin altındaki neon lambalar tarafından aydınlatılır. Konușmanın konusu bilinmeyen, yasadışı bir işle ilgilidir ve buradaki aşağıdan yukarı yönlü aydınlatma oluşturduğu etkiyle sahnenin anlamını güçlendirir.

Filmin karşıtllı̆ı ve renkleri normal değerlerdedir. Filmde gözün görüş alanına denk geniş açılı bir objektif ve geniş bir çerçeve oranı kullanılmıştır. Filmde sıklıkla seyirciyi karakterlere yakın bir mesafede konumlandıran omuz ve göğüs çekim ölçekleri kullanılmıştır. Kamera tümüyle nesnel bir bakış açısında, karakterlerin göz seviyesinde, elde ve hareketli olarak kullanılmıştır. Kamera film boyunca yalnızca karakterleri takip etmektedir. Bu durum anlatımda bazı ögelerin çerçeve dışında kalmasına yol açmaktadır. Filmin yoğun eylem içeren sahnelerindeki telaş kamera kullanımına da yansır. Bu sahnelerdeki sarsıntılı kamera filme belgesel veya haber filmi benzeri gerçekçi bir görünüm kazandırır.

\subsubsection{Ses}

Victoria'da karakterlerin sesleri yalnızca diyalog şeklinde yer almaktadır. Oyunculukta olduğu gibi diyaloglarda da doğaçlamadan faydalanılmıştır. Film gerçek mekânlarda, sesli olarak çekilmiştir. Filmdeki tüm ses efektleri gerçekçidir. Çerçeve dışı sesin polisten kaçış sahnelerinde geciktirim etkisi vardır. Victoria'da müziğin hem fonda hem de sahne içinde kullanımı söz konusudur. Filmde çatıya çıkıș, mafyaya gidiş, mafyadan dönüş, soyguna gidiş, soygun sonrasında gece kulübündeki kutlama, polisten kaçış, polisle çatışma, Sonne'nin ölümü ve Victoria'nın otelden ayrilıp caddede yürüyerek uzaklaşması sahnelerinde fon müziği kullanılmıştır. Çatıya çıkış sekansında ve soygun sonrasında gece kulübündeki kutlama sahnesinde filmin tüm sesleri kısılarak yalnızca fon müziğinin duyulması sağlanmıștır. Victoria'nın kafede piyano çalışı ile gece kulübünde, taksi radyosunda, otel lobisi, tuvaleti ve asansöründe duyulan müzikler filmde sahne içi müziğin kullanıldığı sahnelerdir. Filmin sonlarında karakterlerin polisle çatışma sahnesindeki fon müziği filmin başlarında birlikte çatıya çıktıkları sahnedeki fon müziğinin bir tekrarıdır.

\subsubsection{Kurgu}

Victoria tek çekim olarak tasarlanmış bir filmdir. Görüntüde kurgunun kullanılmaması filmin anlatımında nesnel ve öznel çekim açıları arasında yer değiştirilmesi imkânını ortadan kaldırmıștır. Filmin temposu tıpkı tiyatrodaki gibi oyuncular tarafından ayarlanmaktadır. Filmin sesinde kurgu kullanılmıştır. Ses kurgusu filmin fon müziği içeren kısımlarının haricinde tümüyle gerçekçi tarzda oluşturulmuştur.

\subsection{AS4: Victoria'da Mekân-Zamansal Süreklilik}

Tek çekimden oluşması nedeniyle Victoria bütünüyle MZS içeren bir filmdir. Filmin farklı mekânları arasındaki geçişler hareketli el kamerası aracılığıyla kesintisiz olarak sağlanmıştır. Victoria'da görüntü kurgusunun kullanılmaması nedeniyle kurgu senaryo ve sahneleme aracılığıyla gerçekleştirilmiştir. Filmin süreklilik içeren olay örgüsü görüntü kurgusunu gerektirmeyen bir yapıda kurulmuştur. Senaryo, görüntü ve ses ögelerinin yerinde kullanımı dramatik yoğunluğun film boyunca neredeyse hiç azalmamasını 
sağlamıştır. Filmin özellikle piyano, soygun, kaçış, polisle çatışma ve bebek kaçırma gibi yüksek dramatik yoğunluklu sahnelerinde MZS’nin anlatımdaki etkisinin arttığ gözlemlenmiştir.

\section{Tartışma}

Araştırmada Victoria filmindeki gerçekçiliğin dalıma göreceli olarak katkı sağladığını söylemek mümkündür. Çünkü yüksek derecede bir dalım gerçekçi bir sanal ortam ile eșdeğer olarak kabul edilse de (Astheimer vd., 1994, s. 190) kișilerin gerçekçilik algısının uzmanlık, duyuşsal duyarlılık, korku, vb. öznel etmenler nedeniyle farklılık gösterdiği bilinmektedir (Astheimer vd., 1994, s. 205-206; Slater ve Usoh, 1993, s. 91; Hodges vd., 1999, s. 11). Bu nedenle Victoria'daki gerçekçiliğin dalıma olan etkisi seyirciler arasında farklılık gösterecektir.

Victoria, Full HD formatında (Victoria technical specifications, 2015), monoskopik olarak çekilmiș bir film olması nedeniyle seyirciye üç boyutlu veya dalımsal bir sinema filmine kıyasla daha düşük seviyede bir fiziksel dalım sunmaktadır. Sinema salonun etkisinin yanı sıra filmin 2.39:1'lik geniş çerçeve oranı ve 5.1'lik çevresel ses bileşimi (Narrative Work, t.y.) fiziksel dalımı sağlayan diğer etmenlerdir. Diğer taraftan söz konusu öykü anlatımı olduğunda fiziksel dalım zorunlu değildir. İyi anlatılan bir öykü karşısında kiși kendi (zihinsel) dalımını kendisi yaratır (Brooks, 2003, s. 4). Dalımı deneyimleme arzumuzdan ötürü dikkatimizi bizi saran dünyaya yöneltiriz ve zihnimizi deneyimin gerçekliğini sorgulamak yerine güçlendirmek üzere kullanırız (Murray, 1997, s. 107). Özetle kişi kendisine anlatılan öyküyü dalıma niyetli olarak takip eder.

Victoria'da senaryo zihinsel dalımı dört yönden de etkilemektedir. Diyaloglarda tekrarlanan Berlin ve Madrid şehir adları senaryodaki mekânsal dalıma sözel olarak katkı sağlamaktadır. Özellikle ünlü şehir adları bu şehirler hiç ziyaret edilmemiş olsa dahi okuyucunun/seyircinin zihnindeki kodları harekete geçirerek hızlı bir dalım oluşturur (Ryan, 2001, s. 128). Senaryonun gerçek zamanlı yapısı, mekân-zamansal dalımı filmde sürekli hale getirerek seyircinin anlatılan olayın meydana geldiği mekâna ve zamana nakledilmesini sağlamıştır (Ryan, 2001, s. 130). Senaryodaki geciktirim unsurlarının seyircide yarattığ merak duygusu zamansal dalımın gerçekleşmesini sağlamaktadır. Ryan (2001) zamansal dalımı, okuyucunun anlatı zamanının sonunda kendisini bekleyen bilgiyi bilme arzusu olarak tanımlar. Geciktirim bu arzunun teknik adıdır (s. 140). Dramatik ironi, hazırlık ve sonuç, ekme ve ödeme, gelecek ögeleri ve bildirme gibi geciktirime yönelik araçların tümü seyircinin öyküye katılımını arttırır (Howard ve Mabley, 1995, s. 69-74). Çünkü bu yolla seyirci öykünün özüne dair içeriden sızdırılmış, gizli, özel bir bilgisi olduğu, sırlar veya yeni anlamlar keşfettiği hissine kapılır (Howard ve Mabley, 1995, s. 72-73). Seyirci Victoria ve diğer karakterlerle özdeşleşmesiyle duygusal dalımı yaşamaktadır. Bir karakter veya durum ile olan özdeşleşme ne denli güçlüyse kurmaca ve gerçeklik, kendimiz ve diğeri arasındaki sınırlar da o denli yıkılma eğilimindedir (Berkowitz'ten aktaran, Ryan, 2001, s. 151).

Victoria tümüyle Berlin'in merkez semti Mitte'deki (Sonja, 2018) gerçek mekânlarda çekilmiştir. Filmin diyalogsuz, yaklaşık yirmi sayfalık bir geliştirim senaryosundan (tretman) hareketle çekilmesi (Filming Victoria movie in one take, 2015) oyunculukta doğaçlamaya imkân tanımıştır. Doğaçlama yöntemi insan davranıșındaki beklenmedik ve öngörülemez olanın keșfinin, ezberlenmiș soyut basmakalıp biçimlerin arınıklığından kaçınmanın bir yoludur. Filmde gerçek durumlardaki gerçek insanlar hissinin oluşturulması belgesel gerçekçiliğini çağrıştırır (Wexman, 1980, s. 29).

Victoria'nın 24 mm'lik, geniş açılı bir objektif ve 2.39:1'lik, geniş bir çerçeve oranı ile çekilmiş olması (Narrative Work, t.y.) filmin görüntüsünü gözün görüş alanıyla eşleştirmiştir. Filmde karakterlerin hareketli el kamerasıyla yakından takip ediliși bir anlamda kameraya öznel bir özellik yüklese de kamera çoğunlukla varlığını seyirciye hissettirmez. Bu nedenle filmde seyirci yönlendirilmiş hissetmemektedir (Filming Victoria movie in one take, 2015). Görüntünün yanı sıra Victoria'daki ses de gerçekçiliğiyle dalımı desteklemektedir. Özellikle çerçeve dışı sesin, filmin dikdörtgen çerçevesinin sınırlarının ötesinde var olan bir dünyanın yanılsamasını yaratması (Sobchack ve Sobchack, 1987, s. 185) nedeniyle dalımda önemli bir payı vardır. Victoria'nın fon müziği içeren sahneleri filmde gerçekçiliğin azaldığı yerlerdir. Nihayetinde fon müziği hiçbir çerçeve içi kaynaktan doğmayan, mantığa aykırı, açıkça mevcut olmayan çerçeve dışı bir sestir (Sobchack ve Sobchack, 1987, s. 188).

Victoria'da görüntü kurgusunun kullanılmaması filmde var olan nesnel bakış açısından öznel bakış açısına geçiş imkânını ortadan kaldırmıştır. Bu durumun seyircinin karakterlerle özdeşleşmesini ve dolayısıyla duygusal dalımı azaltan bir etkisi vardır. Filmde bir yere doğru bakan bir karakterin çekiminin ardından karakterin gördüğü yerin çekiminin gösterilmesi aslında seyirciyi karakterin yerine geçirir ve sahneyi karakterin gözlerinden görmesini sağlar (Barka2000, 2007). Oysa filmde kesme kullanılmadan bir karakterin baktığı yerin gösterilmesi ancak kameranın o yere çevrilmesi yoluyla mümkün olabilir. Bu 
durumda kamera ve aynı zamanda seyirci sahnede üçüncü bir şahıs konumunda kalır. Ayrıca Victoria'nın geniş çerçeve oranının filmin kurgu ihtiyacının azalmasına katkı sağladığı söylenebilir. Çünkü geniş çerçeve oranı tıpkı genel çekim gibi kompozisyona daha çok öge sığdırabilmesi sayesinde filmde kesme ihtiyacını azaltır (Reisz ve Millar, 1953/2014, s. 284).

Filmde süreklilik halindeki görüntü ve ses, seyirciye gerçek bir olaya tanıklık ettiği hissini yaşatır (Sobchack ve Sobchack, 1987, s. 158). Bu nedenle MZS'nin Victoria'nın görüntüsünde ve sesinde olușturduğu gerçekçilik hem fiziksel hem zihinsel dalıma katkı sağlamaktadır. Dilin dalımı yaratabilmesi için kendisini görünmez hale getirmesi gereklidir (Ryan, 2001, s. 159). Dolayısıyla Victoria'nın eşzamanlı anlatımıyla oluşan MZS, seyircinin burada ve şimdide hissederek mekân-zamansal dalımı yaşamasını sağlayan temel etmendir.

MZS'nin Victoria'daki oyunculuk üzerinden de dalıma katkı sağladığı gözlemlenmiştir. Tiyatrodan farklı olarak sinemada oyuncunun oyununu kamera aracllığıyla sergilemesi buradalığını ve dolayısıyla halesini yitirmesine yol açar (Benjamin, 1935/2013, s. 65-68). Bu noktada tek çekimin sunduğu süreklilik oyuncunun perdedeki gerçekçiliğini arttırarak ona yitirmiş olduğu halesini bir ölçüde geri alma olanağı tanımaktadır.

Filmde eylem ve tepkiler arasında bırakılan zaman dramatik bir işlevi olmadığı takdirde ziyan edilmiş bir zamandır (Reisz ve Millar, 1953/2014, s. 191). Dramatik yoğunluğun yükselmesi ise filmde kesmeye olan ihtiyacı azaltır. Buna göre MZS'nin Victoria'daki anlatıma ve dalıma olan katkısının filmin dramatik yoğunluğu yüksek sahnelerinde görece daha fazla olduğu söylenebilir.

Victoria'da MZS'nin kurguyu devre dışı bırakması nedeniyle öznel bakış açısına geçişe imkân vermemesinin duygusal dalımı azaltıcı etkisine değinilmişti. Bunun dışında Victoria'daki MZS'nin dalımı desteklediği görülmüştür.

Bu araştırmanın sınırlılı̆̆ı, buradalığın (zihinsel dalım) öznel bir his olması (Sheridan, 1992, s. 121) nedeniyle nesnel olarak değerlendirilememesidir. Dolayısıyla araştırmada MZS'nin Victoria'daki dalımı tam olarak ne ölçüde etkilediğinin saptanması imkânı olamamıştır. Bunun yerine MZS'nin Victoria'daki dalımı nasıl etkilediği araştırılmış ve dalımdaki diğer etmenler ile kıyaslaması yapılmıştır.

Öte yandan Victoria'nın anlatı türünde bir film olmasından hareketle senaryonun zihinsel dalımın temel etmeni olduğu söylenebilir. Araştırmada senaryodaki dalım Ryan'ın (2001) sınıflandırmasına göre mekânsal, mekân-zamansal, zamansal ve duygusal olmak üzere dört başlıkta incelenmişti (s. 121). Buna göre senaryodaki mekân-zamansal dalımı oluşturan MZS, Victoria'daki zihinsel dalımın dört temel etmeninden biridir. Bunlar arasında öne çıkanların ise senaryodaki zamansal dalımı oluşturan geciktirim ve duygusal dalımı oluşturan özdeşleşme unsurları olduğunu söylemek mümkündür. Çünkü seyircinin öyküye olan ilgisini ve katılımını sağlayan unsurlar bunlardır (Howard ve Mabley, 1995, s. 22, 69-74). MZS'nin ise anlatımda böylesi bir işlevi yoktur. Ayrıca görünmez kurgu (invisible editing) yöntemi ve daha önemlisi günümüz seyircisinin film diline alışkınlığı dolayısıyla kurgu filmde çoğunlukla göz ardı edilen bir unsurdur (Sobchack ve Sobchack, 1987, s. 117). Dahası seyirci anlatı süresi içine bütünüyle çekildiğinde dalımı yaşamakta olduğu için film süresinin nasıl geçtiğinin farkına varmaz (Brooks, 2003, s. 5). Bu nedenle Victoria'da MZS'nin dalımdaki temel etmenlerden biri olsa da birincil etmen olmadığını söylemek mümkündür.

\subsection{Sonuç}

Araştırmada gerçekçiliğin öznel bir kavram olması nedeniyle Victoria'daki dalıma göreceli olarak katkı sağladığı görülmüştür. Victoria'daki fiziksel dalım filmin gösterim mekânı, geniş çerçeve oranı ve çevresel ses bileşimi aracılığıyla gerçekleşmektedir. Zihinsel dalımın oluşumunda filmin tüm ögelerinin etkisi bulunmaktadır. Victoria'daki MZS'nin seyircinin burada ve şimdide hissetmesini sağlayan, bu nedenle dalımı çoğunlukla arttıran bir etkisi vardır. Ancak zihinsel dalımın öznel bir his olması tüm bu etkilerin nesnel olarak saptanmasına imkân vermemektedir. Diğer taraftan Victoria'nın bir anlatı filmi olmasından hareketle, senaryodaki MZS'nin filmdeki zihinsel dalımın temel etmenlerinden biri olduğu söylenebilir. Zihinsel dalımdaki birincil etmenlerin ise senaryodaki geciktirim ve özdeşleșme unsurları olduğunu söylemek mümkündür. Çünkü seyircinin öyküye olan ilgisini ve katılımını bu unsurlar sağlamaktadır. Sonuç olarak Victoria filminde MZS'nin dalımın birincil etmeni olmadığı varsayımında bulunulabilir.

\section{2. Öneriler ve Gelecek Çalışmalar}

Victoria'da tek çekim aracılığıyla filmin bütününde MZS'nin sağlanması, dalımı arttırmasına karşın anlatımı büyük ölçüde sınırlandırmaktadır. İdeal olan, anlatımda araçların ihtiyaca göre kullanılmasıdır. Benzer bir durum anlatımın bütünüyle başkarakterin bakış açısından yapıldığı, Montgomery'nin Lady in the Lake 
(Göldeki Kadın, 1946) adlı filminde vardır. Bu filmde özdeşleşmenin arttırılması amacıyla kameranın tümüyle öznel bakış açısında tutulması anlatıma kendine has sınırlar getirmiştir. Elbette bu sınırlar geleneksel film anlatısına göre bir değerlendirme için geçerlidir. Örneğin sanal gerçeklik için tek çekim veya öznel bakış açısı, aracın doğal bir parçası olarak görülebilir. Bu anlamda Victoria ve benzeri tek çekim filmler sinema sanatının gelișimi ve evrimi için önemli denemelerdir.

MZS'nin dalım üzerindeki etkisi ile ilgili gelecek çalıșmalar, anlatısal olmayan (non-narrative), deneysel filmlere yönelik olabilir. Bu tür filmlerde, tıpkı sanal gerçeklik filmlerindeki gibi seyircinin buradalık hissi birincil önemde olduğu için MZS’nin dalımdaki payı daha fazla olacaktır.

\section{Teşekkür}

Bu araştırmanın yazım sürecindeki öneri ve yol göstericilikleri için babam Selim Yücel'e, hocalarım Pınar Eraslan Yayınoğlu ve Mehmet Yayınoğlu'na teşekkür ederim.

\section{Kaynakça}

Anagnorisis. (2017). Literary devices online dictionary içinde. Erișim adresi: https://literarydevices.net/anagnorisis/

Arcimboldo, G. (1563). Sommer [Ihlamur ağacı üzerine yağlı boya]. Kunsthistorisches Museum, Wien. Erişim Adresi: https://www.khm.at/objektdb/detail/71/

Aristoteles. (2018). Poetika- şiir sanatı üzerine (A. Çokona, Ö. Aygün, Çev.) (4. b.). İstanbul: Türkiye İş Bankası Kültür Yayınları.

Astheimer, P., Dai, F., Göbel, M., Kruse, R., Müller, S. ve Zachmann, G. (1994). Realism in virtual reality. In Thalmann, N. M. and Thalmann, D. (ed.), Artificial life and virtual reality (pp. 189-210), Chichester: John Wiley \& Sons.

Ayzenștayn, S. M. (Yönetmen/Senaryo Yazarı). (1925). Bronyenosyets Potyomkin. [Film]. Sovyetler Birliği: Mosfilm.

Barka2000 (2007, Mart 5). Virgil Widrich - interview. [Youtube Video]. Erişim adresi: https://www.youtube.com/watch?v=82ScuD7Srvo

Başol, Ö. (2010). Senaryo kitabı: Senaryo yazım teknikleri ve film örnekleri (1. b.). İstanbul: Pana Film Yayınları.

Bazin, A. (1967/2005). What is cinema? Volume I (H. Gray, Trans.). Los Angeles: University of California Press.

Bell, J. S. (2011). Elements of fiction writing - Conflict and suspense (1st ed.). London: Penguin Books.

Benjamin, W. (1935/2013). Fotoğrafın kısa tarihi/teknik araçlarla yeniden-üretim (çoğaltma) çağında sanat eseri (0. Akınhay, Çev.) (2. b.). İstanbul: Agora Kitaplığı.

Brooks, K. (2003). There is nothing virtual about immersion: Narrative immersion for VR and other interfaces. Erişim adresi:

https://www.researchgate.net/publication/228764946_There_is_nothing_virtual_about_immersi on_Narrative_immersion_for_VR_and_other_interfaces

Cawgill, L. J. (2007). The art of plotting, add emotion, suspense, and depth to your screenplay (1st ed.). Los Angeles: Lone Eagle.

Egri, L. (1960). The art of dramatic writing, its basis in the creative interpretation of human motives. New York: Simon \& Schuster.

Ehrlich, D. (2015, Ekim 9). This director of this movie shot in a single take doesn't resent birdman, actually. Vanity Fair. Erişim adresi: https://www.vanityfair.com/hollywood/2015/10/victoriadirector-interview

Filming Victoria movie in one take. (2015). Erișim adresi: https://cpn.canoneurope.com/content/education/technical/filming_victoria_movie_in_one_take. do (Erişim tarihi: 11 Mayıs 2020) 
Hodges, L. F., Rothbaum, B. O., Watson, B. A., Kessler, G. D. ve Opdyke, D. (1999). Virtual reality exposure for fear of flying therapy. IEEE Computer Graphics \& Applications, 16(6), 42-49. Erişim adresi: https://www.researchgate.net/publication/2447495_Virtual_Reality_Exposure_for_Fear_of_Flyin g_Therapy

Hornby, A. S. (1989). Oxford advanced learner's dictionary of current English (4th ed.). Oxford: Oxford University Press.

Howard, D. ve Mabley, E. (1995). The tools of screenwriting: A writer's guide to the craft and elements of a screenplay (1st ed.) New York: St. Mrtin's Griffin.

Mascelli, J. V. (1965). The five c's of cinematography, motion picture filming techniques. Los Angeles: SilmanJames Press.

Merriam, S. B. (2015). Nitel araştırma desen ve uygulama için bir rehber (S. Turan, Çev. Ed.) (3. b.). Ankara: Nobel Akademik Yayıncıllk.

Mills, A. J., Eurepos, G. ve Wiebe, E. (ed.). (2010). Encyclopedia of case study research (Vol. 1). Los Angeles: Sage Publications.

Montgomery, R. (Yönetmen). (1946). Lady in the lake. [Film]. ABD: Metro-Goldwyn-Mayer.

Murray, J. H. (1997). Hamlet on the holodeck: The future of narrative in cyberspace. New York: Free Press.

Narrative Work. (t.y.). Victoria. [Video]. Sturla Brandth Grøvlen, DFF. Erişim adresi: https://www.sturla.dk/

Rayfield, D. (1997). Anton Chekhov: A life (1st ed.). Illinois: Northwestern Univesity Press.

Reisz, K. ve Millar. G. (1953/2014). The technique of film editing (2nd ed). Boston: Focal Press.

Ryan, M. L. (2001). Narrative as virtual reality, immersion and interactivity in literature and electronic media (1st ed.). Baltimore, Maryland: The Johns Hopkins University Press.

Schipper, S. (Yönetmen/Senaryo Yazarı). (2015). Victoria. [Film]. Berlin: MonkeyBoy, Deutschfilm, Radical Media, Westdeutscher Rundfunk (WDR), ARTE.

Sheridan, T. B. (1992). Musings on telepresence and virtual presence. PRESENCE: Teleoperators and Virtual Environments, 1(1), 120-126. doi: 10.1162/pres.1992.1.1.120

Sherman, W. R. ve Craig, A. B. (2003). Understanding virtual reality: interface, application, and design. San Francisco: Morgan Kaufman Publishers.

Simon, J. L. (1978). Basic research methods in social sciences: The art of empirical investigation. New York: Random House.

Slater, M. ve Usoh, M. (1993). Presence in immersive virtual environments. Proceedings of the IEEE 1993 Virtual Reality Annual International Symposium (VRAIS), 90-96. doi: 10.1109/VRAIS.1993.380793

Slater, M., Linakis, V., Usoh, M. ve Kooper, R. (1999). Immersion, presence, and performance in virtual environments: An experiment with tri-dimensional chess. VRST '96: Proceedings of the ACM Symposium on Virtual Reality Software and Technology, 163-172. Erişim adresi: https://www.researchgate.net/publication/2633779_Immersion_Presence_and_Performance_in_ Virtual_Environments_An_Experiment_with_Tri-Dimensional_Chess

Slater, M. (2003). A note on presence terminology. [pdf]. A note on presence terminology. Erişim adresi: http://s3.amazonaws.com/publicationslist.org/data/melslater/ref201/a\%20note\%20on\%20presence\%20terminology.pdf

Sobchack, T. ve Sobchack, V. C. (1987). An introduction to film (2nd ed.). Boston: Little Brown and Company.

Sonja. (2018, Ağustos 5). "Victoria" Film Locations Walk in Berlin. FilmFanTravel. Erişim adresi: https://filmfantravel.com/victoria-film-locations-walk-in-berlin/

Sophokles. (M.Ö. 428/2012). Kral Oidipus. (B. Tuncel, Çev.). İstanbul: Türkiye İș Bankası Kültür Yayınları.

Victoria technical specifications. (2015). IMDB. Erişim adresi: https://www.imdb.com/title/tt4226388/technical?ref_=tt_dt_spec 
Wexman, V. W. (1980). The rhetoric of cinematic improvisation. [Özel sayı]. Cinema Journal, 20(1), 29-41. doi: $10.2307 / 1224969$

Witmer, B. G. ve Singer, M. J. (1998). Measuring presence in virtual environments: A presence questionnaire. Presence: Tele-operators and virtual environments, 7(3), 225-240. doi: $10.1162 / 105474698565686$

Yin, R. K. (2014). Case study research: Design and methods (5th ed.). Los Angeles: Sage Publications.

Yu, K. C., Neafus, D. ve Wyatt, R. (2016). Filmmaking for fulldome: Best practices and guidelines for immersive cinema (Part I). Planetarian, 45(4), 27-39. Erișim adresi:

https://www.academia.edu/31687220/Filmmaking_for_the_Fulldome_Best_Practices_and_Guidel ines_for_Immersive_Cinema_Part_I_ 